\title{
Allele-specific Emulsion PCR (asePCR) as a Liquid Biopsy Method for Residual Tumor Detection
}

\section{Rezidüel Tümör Tespiti İçin Bir Sıvı Biyopsi Yöntemi Olarak Alel- spesifik Emülsiyon PCR (asePCR)}

\begin{abstract}
Aim: This study aimed to develop an allele-specific emulsion polymerase chain reaction (asePCR) technique for detection of cell-free circulating tumor DNA (ctDNA) in the blood plasma of cancer patients.

Materials and Methods: Genomic DNA extracted from normal (wild-type) and thyroid cancer (mutant) cell lines (MCF10A and B-CPAP) were used to obtain specific dilution series (spike-in) of mutant DNA with wild-type DNA. Two sequential PCR steps (regular and asePCR) were performed with specifically designed primers for each step to detect the spiked-in mutant DNA fraction within the wild-type normal DNA. The DNA products amplified by regular PCR were used as templates in the asePCR where specific reverse primers were designed to amplify either the mutant or wild-type allele while a common forward primer was covalently bound to the beads. The asePCR reaction mix was encapsulated in water-in-oil emulsion compartments and incubated in a thermocycler with specific PCR program settings. At the end of asePCR reaction, oil compartments were broken and DNA-coated beads were evaluated by FACS to determine the mutant and wild-type fractions for each sample.

Results: The asePCR technique successfully detected the mutant DNA in the background of wildtype DNA ( $0 \%$ mutant) as a proof-of-principle. A strong correlation ( $r 2>0.99)$ was found between the expected mutant fraction and the fraction measured by asePCR. asePCR was sensitive and specific enough to consistently detect various low mutant DNA fractions in the background of wild-type DNA with no false positives in the wild-type sample.

Discussion and Conclusion: Our asePCR can be used to detect mutant ctDNA in the plasma of cancer patients as a liquid biopsy method for tumor response evaluation and early detection of possible relapses.
\end{abstract}

Keywords: cancer; cfDNA; ctDNA; digital PCR; emulsion-PCR; liquid biopsy

Öz

Amaç: Bu çalışmada kanser hastalarının kan plazmasında sirkülasyondaki hücresiz tümör DNA'sının (ctDNA) saptanışına yönelik alel-spesifik bir emülsiyon polimeraz zincir reaksiyonu (asePCR) tekniği geliştirmek amaçlanmıştır.

Gereç ve Yöntemler: Normal tip DNA ile mutant DNA'nın spesifik seyreltisini (spike-in) elde etmek için, normal (doğal tip) ve tiroit kanserli (mutant) hücre hatlarından (MCF10A ve B-CPAP) ekstrakte edilen iki tip genomik DNA kullanıldı. asePCR tekniğimizi doğrulamak için BRAFV600E hotspot mutasyonu hedeflendi. İki sıralı PCR adımı (düzenli ve asePCR), normal DNA içindeki mutant DNA fraksiyonunu tespit etmek için her bir adım için özel olarak tasarlanmış primerler ile gerçekleştirildi. Düzenli PCR ile çoğaltılan DNA örnekleri, asePCR'de spesifik olarak tasarlanmış mutant ve normal tip alel-spesifik primerler ve ortak primer ile kovalent olarak bağlanmış olan tanecikler ile birlikte kullanılmıştır. asePCR reaksiyon karışımı, mineral yağ içinde su emülsiyon bölmelerinde kapsüllendi ve spesifik PCR program ayarları ile bir termosistörde inkübe edildi. asePCR reaksiyonunun sonunda, mineral yağ bölmeleri kırıldı ve DNA kaplı taneler FACS ile değerlendirildi ve her örnek için mutant ve normal tip fraksiyonları sayıldı.

Bulgular: AsePCR tekniği, prensip kanııı olarak normal tip DNA'nın (\%0 mutant) arka planında mutant DNA'yı başarıyla tespit etti. Bilinen mutant fraksiyonu ile asePCR ile ölçülen fraksiyon arasında güçlü bir korelasyon $(r 2>0,99)$ bulundu. AsePCR, normal tipteki örnekte hiçbir yanlış pozitiflik tespit etmediği gibi normal tip örnekteki DNA'nın arka planındaki çeşitli düşük mutant DNA fraksiyonlarını da tutarlı bir şekilde tespit edecek kadar hassas ve spesifikti.

Tartışma ve Sonuç: asePCR tekniğimiz, tümör yanıtını değerlendirmeye ve olası relapsları erken teşhise yönelik bir sıvı biyopsi yöntemi olarak, kanser hastalarının plazmasında mutant ctDNA tespiti için kullanılabilir.

Anahtar Sözcükler: ctDNA; cfDNA; dijital PCR; emülsiyon-PCR; kanser; sıvı biyopsi

\section{Bedri Karakas}

King Faisal Specialist Hospital and Research Center
Received/Geliş : 08.07.2018 Accepted/Kabul: 09.09.2018

DOI: 10.21673/anadoluklin.441594

Corresponding author/Yazışma yazarı Bedri Karakas

P.O. box 3354 MBC-03, Riyadh, 11211 Saudi Arabia

E-mail: bkarakas@kfshrc.edu.sa 


\section{INTRODUCTION}

Cell-free DNA (cfDNA) has been known to circulate in the blood plasma since the late 1940s (1). This important observation did not get enough attention until the mid-1970s (2). The levels of cfDNA were reported to increase in the plasma or serum of sick people, including cancer patients (3-5). In later years, however, it was found that the simple increase in cfDNA levels was not sensitive enough to be used as a disease marker due to both genetic variation and other environmental exposures (6). In cancer patients, attempts have been made to specifically quantify the plasma (cell-free) circulating tumor DNA (ctDNA) along with normal DNA (7). An advanced molecular technique such as polymerase chain reaction (PCR) allowed researchers to evaluate the cfDNA both quantitatively and qualitatively.

Polymerase chain reaction technique has become a core technique in almost every molecular biology laboratory (8). Since its introduction, many variations of it such as RT-PCR, real-time PCR, digital PCR, and emulsion PCR (emPCR) have been developed (8-10). Most recently, emulsion PCR has been utilized in various genetic applications, especially in detection of mutant DNA in tumor tissues as well as ctDNA in plasma samples (11).

Digital PCR techniques made it possible to detect as few as $2-3$ copies of ctDNA in a milliliter of a patient's plasma (10-14). While highly sensitive in detecting very rare variants in the background of common ones, it is also prone to produce false positives and false negatives. Single nucleotide variations especially can generate false positives when differentiating between variant alleles, such as mutant and wild-type, during the detection step.

In this proof-of-principle study, we modified the emPCR (BEAMing) (15) into an allele-specific emulsion PCR (asePCR) technique in order to reduce false positivity, especially during the detection of ctDNA in the plasma. Our asePCR technique was sensitive enough to accurately detect the known mutant DNA fraction in the spiked-in mutant sample and specific enough to avoid false positives in the wild-type control sample.

\section{MATERIALS AND METHODS}

\section{DNA isolation}

Genomic DNA was isolated from the tissue-cultured normal mammary epithelial (MCF10A, BRAF wildtype) and thyroid cancer (B-CPAP, BRAFV600E) cell lines using Qiagen DNeasy Blood \& Tissue Kit (cat\# 69504) by following the manufacturer's instructions. Cell lines were grown in their respective media and into $80-90 \%$ confluency, trypsinized and centrifuged at $3000 \mathrm{rpm}$ in a cold centrifuge for 5 minutes. The cell pellet was resuspended in lysis buffer and DNA was isolated and eluted in $100 \mathrm{ml}$ elution buffer.

\section{Verification of the BRAFV600E status}

The MCF10A is known to be wild-type for the BRAF hotspot mutation site while B-CPAP cell line is positive for the BRAFV600E. We further verified this by sequencing the DNA isolated from these cell lines by the Sanger sequencing method.

\section{Primer and probe design}

We used primers for each of the two consequent PCR steps. In the first PCR step (regular), primers were designed to amplify regions harboring the DNA variant in question. These primers amplify both DNA types (mutant and wild-type) equally without any preference since the variation is in the middle of the target sequence. In the second PCR step, primers for each mutant and wild-type DNA were designed, the variant being in the middle of the primers, each with a specific tail sequence (Figure 1 and 2). Two separate probes, each labeled with a specific fluorophore, were designed to target the tail sequence of either mutant or wild-type primer (Figure 2).

Regular PCR and spike-in BRAFV600E in the wild-type DNA

The DNA region that harbored BRAFV600E hotspot mutation $(\sim 130 \mathrm{bp})$ was amplified by regular PCR using common primer pair with tail sequences (Figure 1) and then the PCR product was quantified by Qubit fluorophore and the copy numbers for this size fragment were estimated as mentioned before (13). Four 10-fold-dilution series of the mutant fractions $(10 \%, 1 \%, 0.1 \%$, and $0.01 \%)$ were prepared by serial mixing of the first PCR mutant and wild-type products. 


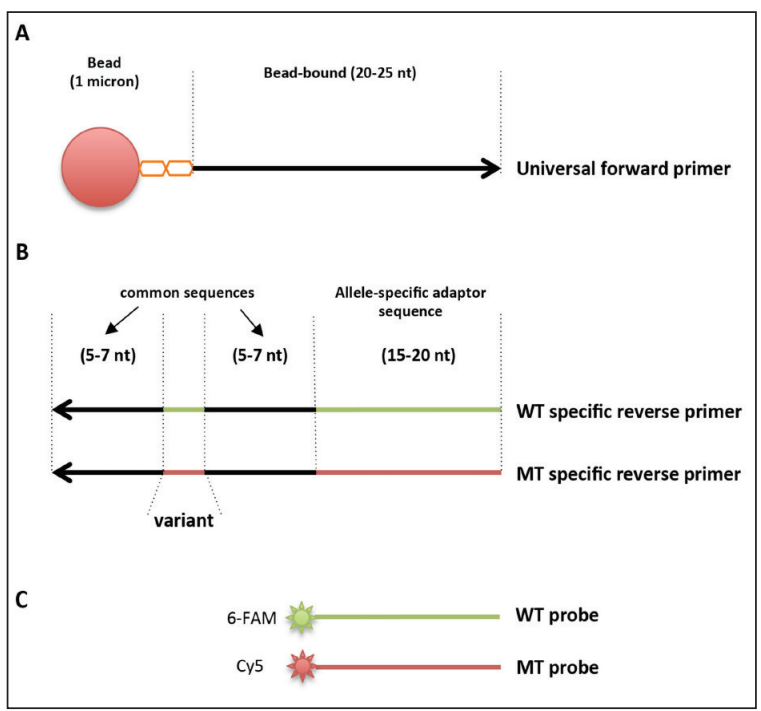

Figure 1. An overall schematic drawing of the allele-specific emPCR (asePCR) for detecting rare DNA variants. A) the common biotinylated forward primer covalently attached to streptavidin-coated magnetic beads; B) wild-type (WT) and mutant (MT) DNA-specific reverse primer with specific tail sequences; C) 5' 6-FAM fluorescently labeled WT tail-specific probe and 5' Cy5 fluorescently labeled MT tail-specific probe.

\section{Preparing the asePCR and thermocycler settings}

The asePCR mix and emulsifications were prepared for each BRAFV600E and BRAF wild-type sample and the rest of the steps were followed as described previously (13). The PCR products amplified from the MCF-10A and B-CPAP DNA samples were serially diluted to get $2 \%$ BRAFV600E DNA with wildtype DNA. The reaction mix (160 ul) composed of 3 $\mathrm{ml}$ of allele-specific reverse primer mix $(100 \mathrm{mM}), 6$ $\mathrm{ml}$ beads bound with forward primer, $8 \mathrm{ml}$ Taq polymerase ( 5 units $/ \mathrm{ml}$ ), and about 5 pg of diluted PCR product (about 120 million copies) was added and the mix was encapsulated in water-in-oil emulsions with an average of $5 \mathrm{mM}$ in size.

Following the formation of water-in-oil emulsions, of which $20 \%$ should have a single DNA template (mutant or wild-type), they were aliquoted into regular PCR tubes and placed in a thermocycler. The set thermal cycling program uses both touchdown and touchup to increase the annealing of allele-specific primers to their respective targets. The thermocycler conditions for the asePCR included the following steps: $\left(95^{\circ} \mathrm{C}\right.$ for $\left.2^{\prime}\right)$ x 1 cycle, $\left(94^{\circ} \mathrm{C}\right.$ for $20^{\prime \prime}$, $70^{\circ} \mathrm{C}$ for $45^{\prime \prime}, 68^{\circ} \mathrm{C}$ for $\left.1^{\prime}\right)$ x 3 cycles; $\left(94^{\circ} \mathrm{C}\right.$ for $20^{\prime \prime}$, $67^{\circ} \mathrm{C}$ for $45^{\prime \prime}, 68^{\circ} \mathrm{C}$ for $\left.1^{\prime}\right)$ x 3 cycles; $\left(94^{\circ} \mathrm{C}\right.$ for $20^{\prime \prime}$, $64^{\circ} \mathrm{C}$ for $45^{\prime \prime}, 68^{\circ} \mathrm{C}$ for $\left.1^{\prime}\right)$ x 3 cycles; $\left(94^{\circ} \mathrm{C}\right.$ for $20^{\prime \prime}$, $61^{\circ} \mathrm{C}$ for $45^{\prime \prime}, 68^{\circ} \mathrm{C}$ for $\left.1^{\prime}\right)$ x 3 cycles; $\left(94^{\circ} \mathrm{C}\right.$ for $20^{\prime \prime}$, $58^{\circ} \mathrm{C}$ for $45^{\prime \prime}, 68^{\circ} \mathrm{C}$ for $\left.1^{\prime}\right) \times 3$ cycles; $\left(94^{\circ} \mathrm{C}\right.$ for $20^{\prime \prime}$, $55^{\circ} \mathrm{C}$ for $45^{\prime \prime}, 68^{\circ} \mathrm{C}$ for $\left.1^{\prime}\right)$ ) 3 cycles; $\left(94^{\circ} \mathrm{C}\right.$ for $20^{\prime \prime}, 64$ ${ }^{\circ} \mathrm{C}$ for $45^{\prime \prime}, 68^{\circ} \mathrm{C}$ for $\left.1^{\prime}\right)$ x 45 cycles. The final annealing temperature during touchdown can be as low as $45^{\circ} \mathrm{C}$ depending on the Tm and \% GC content of the allele-specific primers.

\section{Detection and quantification}

After asePCR, samples were processed and individual DNA-coated beads (either wild-type or mutant) were isolated and counted by FACS as described previously (13). The emulsions were broken down and beads were isolated and resuspended in $100 \mathrm{ml}$ TE buffer. A $20 \mathrm{ml}$ aliquot from suspended beads of each sample (wild-type and 2\% BRAFV600E mutant) was mixed with $1 \mathrm{mM} 5$ 'fluorescently labeled probes (specific for both wild-type and mutant DNA) in a $100 \mathrm{ml}$ volume mix and placed in a thermocycler to carry out the hybridization reaction (Figure 2). After the reaction, beads were washed with wash buffer and then resuspended in $300 \mathrm{ml}$ wash buffer. Finally, the number of mutant and wild-type beads were counted by a FACS machine.

\section{RESULTS}

When mutant DNA was spiked in the background of wild-type DNA in four 10-fold serial dilutions, asePCR accurately estimated the mutant fraction percentage in all these four samples. There was a strong correlation $\left(\mathrm{r}^{2}>0.99\right)$ between the known mutant fractions and the fractions estimated by asePCR (Figure 3 ). The asePCR detected a mutant fraction of $0.01 \%$ in the wild-type background (Figure 3).

Besides, asePCR did not produce any false positive results in the control sample that was wild-type DNA for BRAF hotspot mutation (Figure 4A) and accurately detected the known mutant DNA fraction (2\%) in the background of wild-type DNA (Figure 4B). 


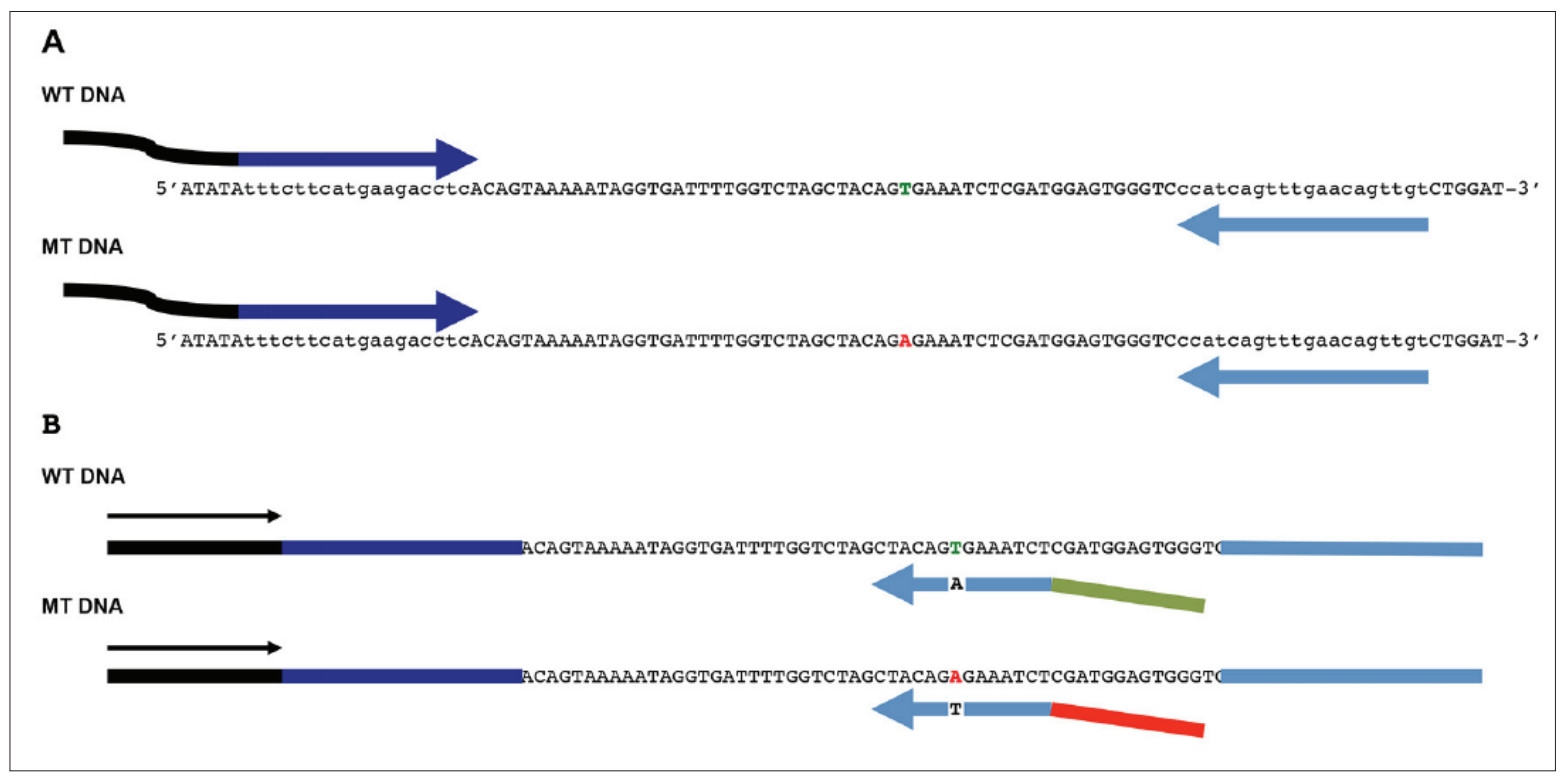

Figure 2. A) common forward primers specific to gene region (blue line) with common adaptors (black line) specific to primer-coated beads and reverse primers designed to amplify the specific gene regions harboring WT and MT DNA in the initial PCR step; B) forward primers attached to the magnetic beads common to both WT and MT DNA, and allele-specific primers to either WT or MT DNA amplified in step A, each with its own specific tail sequences. The tail sequences to be annealed by specific probes, each labeled with a separate fluorophore to detect both WT and MT DNA-coated beads by FACS.

\section{DISCUSSION AND CONCLUSION}

We modified an in-house emulsion-based digital detection technique known as BEAMing to the asePCR technique to detect rare plasmatic ctDNA in cancer patients with high sensitivity and specificity (15). This original technique was also used in clinical samples of several cancer types and in detecting fetal DNA in the maternal blood circulation through a laborious long protocol, especially during the hybridization of the probes producing nonspecific false positivity $(11,13,16)$

The specificity of the DNA probes for the desired DNA targets is critical to avoid false positives as well as false negatives. Reaching the highest specificity and sensitivity is more challenging, especially in detecting a mutant variant that is very rare in the plasma of cancer patients. The asePCR is a digital detection technique that is open to modification for various nucleic acid variants (DNA or RNA) across all the genome as opposed to commercially available technologies.

Currently there are several commercially available digital PCR platforms with various sensitivity that use TaqMan chemistry for high specificity (17). Since they are proprietary, these platforms are not open to modi- fication except by the companies that provide costly reagents for only one mutant target at a time. asePCR can be used for many DNA mutations as well as for the digital detection of other nucleic acids such as mRNA and miRNAs.

In conclusion, asePCR is a very specific and sensitive technique in detecting rare mutant DNA and can

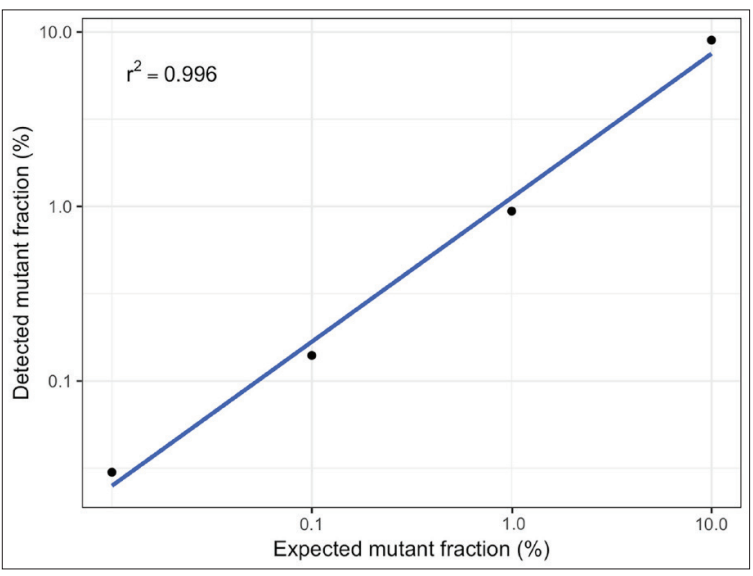

Figure 3. Serial dilution series of BRAFV600E mutant DNA with the wild-type DNA. Mutant DNA was diluted in 10-fold four dilution series ( $10 \%$ to $0.01 \%$ mutant) and samples were amplified by asePCR and counted by FACS and the values of known versus measured mutant fractions were graphed. There is a strong correlation between the expected and measured mutant fraction $\left(r^{2}>0.99\right)$. 

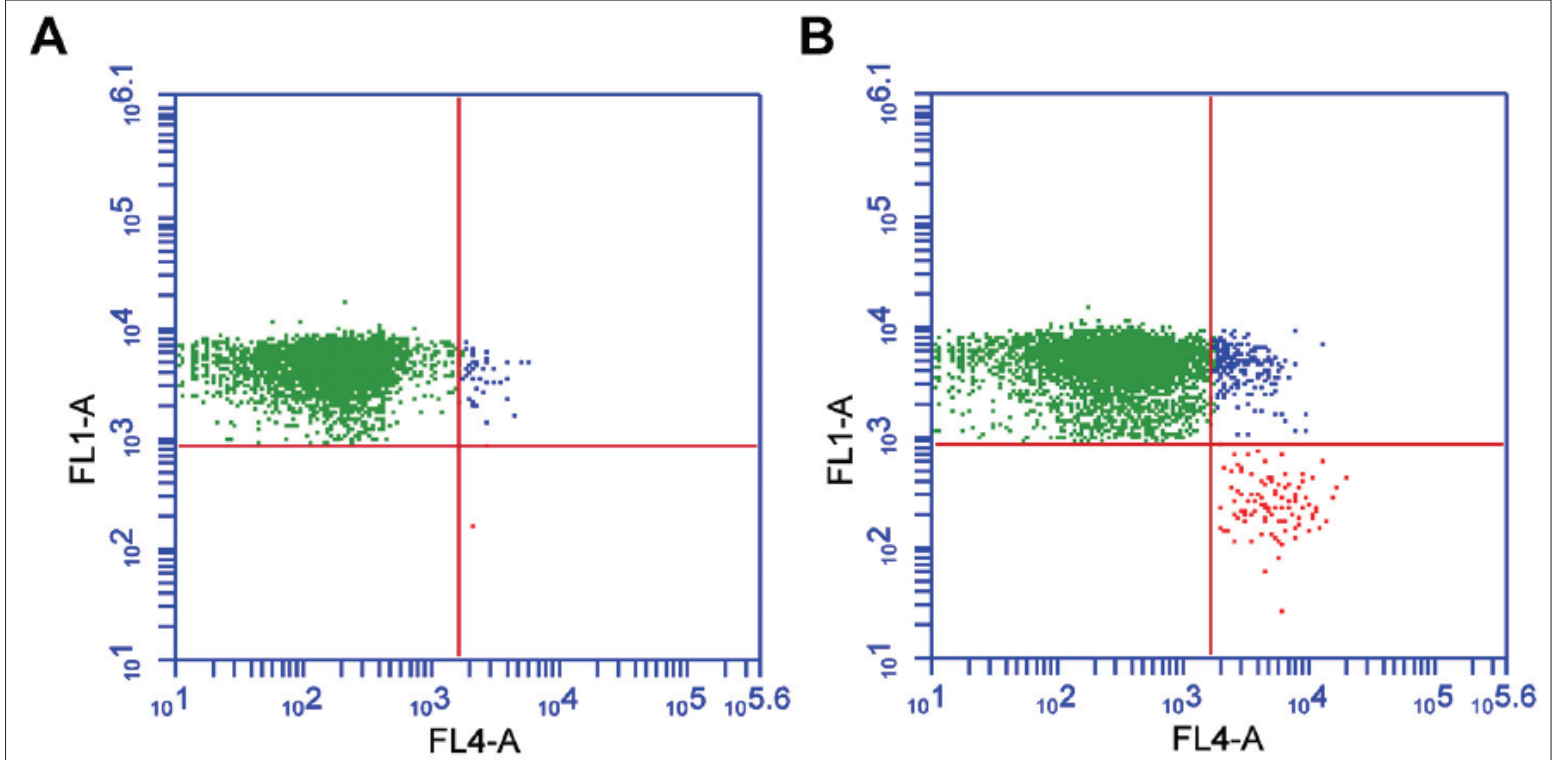

Figure 4. Representative FACS analysis of the asePCR results with A) wild-type DNA-coated beads (green events) and B) $2 \%$ mutant DNAcoated beads (red events). Wild-type DNA-coated beads are targeted by a probe labeled with 6-FAM (FL1) and mutant DNA-coated beads with a probe labeled with Cy5 (FL4).

be used for detecting rare mutations in tumors, blood plasma, and other body fluids. It can also be applied to targeting multiple mutations from the same specimen.

\section{Acknowledgements}

The author thanks the King Faisal Specialist Hospital and Research Center Administration for their support and Ms. Hannah Almubarak for critically reading the manuscript. This project was supported by the Kingdom of Saudi Arabia National Science, Technology and Innovation Plan (NSTIP) strategic technologies in the Kingdom-Award No 12-BIO951-20.

\section{Statement of Conflict of Interest}

The author has no conflict of interest to declare.

\section{REFERENCES}

1. Mandel P. Les acides nucleiques du plasma sanguin chez l'homme. CR Acad Sci Paris. 1948;142:241-3.

2. Steinman CR. Free DNA in serum and plasma from normal adults. J Clin Invest. 1975;56(2):512-5.

3. Steinman CR, Ackad A. Appearance of circulating DNA during hemodialysis. Am J Med. 1977;62(5):693-7.

4. Steinman CR. Circulating DNA in systemic lupus erythematosus. Isolation and characterization. J Clin Invest. 1984;73(3):832-41.

5. Leon SA, Shapiro B, Sklaroff DM, Yaros MJ. Free DNA in the serum of cancer patients and the effect of therapy.
Cancer Res. 1977;37(3):646-50.

6. Lo YMD. Circulating nucleic acids in plasma and serum: an overview. Ann N Y Acad Sci. 2001;945(1):1-7.

7. Maire F, Micard S, Hammel P, Voitot H, Lévy P, Cugnenc $\mathrm{P}-\mathrm{H}$, et al. Differential diagnosis between chronic pancreatitis and pancreatic cancer: value of the detection of KRAS2 mutations in circulating DNA. Br J Cancer. 2002;87(5):551-4.

8. Mullis KB. The unusual origin of the polymerase chain reaction. Sci Am. 1990;262(4):56-61, 64-5.

9. Jones NL. PCR. Principles, procedures, and parameters. Methods Mol Biol. 2002;187:37-46.

10. Dressman D, Yan H, Traverso G, Kinzler KW, Vogelstein B. Transforming single DNA molecules into fluorescent magnetic particles for detection and enumeration of genetic variations. Proc Natl Acad Sci U S A. 2003;100(15):8817-22.

11. Diehl F, Schmidt K, Choti MA, Romans K, Goodman $\mathrm{S}$, Li M, et al. Circulating mutant DNA to assess tumor dynamics. Nat Med. 2007;14(9):985-90.

12. Vogelstein B, Kinzler KW. Digital PCR. Proc Natl Acad Sci. 1999;96(16):9236-41.

13. Karakas B, Qubbaj W, Al-Hassan S, Coskun S. Noninvasive digital detection of fetal DNA in plasma of 4-weekpregnant women following in vitro fertilization and embryo transfer. PLoS One. 2015;10(5):e0126501.

14. Cohen JD, Li L, Wang Y, Thoburn C, Afsari B, Danilova $\mathrm{L}$, et al. Detection and localization of surgically resect- 
able cancers with a multi-analyte blood test. Science. 2018;359(6378):926-30.

15. Diehl F, Li M, He Y, Kinzler KW, Vogelstein B, Dressman D. BEAMing: single-molecule PCR on microparticles in water-in-oil emulsions. Nat Meth. 2006;3(7):5519.

16. Higgins MJ, Jelovac D, Barnathan E, Blair B, Slater S, Powers $\mathrm{P}$, et al. Detection of tumor PIK3CA status in metastatic breast cancer using peripheral blood. Clin Cancer Res. 2012;18(12):3462-9.

17. Day E, Dear PH, McCaughan F. Digital PCR strategies in the development and analysis of molecular biomarkers for personalized medicine. Methods. 2013;59(1):101-7. 